OPEN ACCESS

Edited by:

Molly D. Anderson,

Middlebury College, United States

Reviewed by:

Yiching Song,

Chinese Academy of Sciences

(CAS), China

Christina McGee Schiavoni, Independent Researcher

Bangkok, Thailand

Jessica Goldberger,

Washington State University,

United States

${ }^{*}$ Correspondence:

Kate Farhall

katherine.farhall@rmit.edu.au

Specialty section:

This article was submitted to

Social Movements, Institutions and

Governance,

a section of the journal

Frontiers in Sustainable Food Systems

Received: 17 June 2020

Accepted: 13 January 2021

Published: 10 February 2021

Citation:

Farhall K and Rickards L (2021) The

"Gender Agenda" in Agriculture for

Development and lts (Lack of)

Alignment With Feminist Scholarship.

Front. Sustain. Food Syst. 5:573424.

doi: 10.3389/fsufs. 2021.573424

\section{The "Gender Agenda" in Agriculture for Development and Its (Lack of) Alignment With Feminist Scholarship}

\author{
Kate Farhall ${ }^{1 \star}$ and Lauren Rickards ${ }^{2}$ \\ ${ }^{1}$ Centre for People, Organisation and Work, College of Business, RMIT University, Melbourne, VIC, Australia, ${ }^{2}$ School of \\ Global, Urban and Social Studies, College of Design and Social Context, RMIT University, Melbourne, VIC, Australia
}

Sustainable food systems require sustainable agriculture. To achieve this, we argue, inclusive approaches are required that incorporate the voices and lived experiences of diverse social groups. In agriculture-based international development efforts (known as Agriculture for Development or A4D), it is increasingly being recognized that sustainable agriculture requires attention to gendered power relations. In the past, gender inequality has been a major barrier to developing inclusive, sustainable food systems, and continues to be so today. At the same time, however, gender is increasingly "on the agenda" in A4D. Yet what sort of agenda is being promoted and to what extent does it reflect progress in feminist scholarship? We examine the burgeoning "gender agenda" through the lens of policy materials produced by prominent A4D organizations. In doing so, we find problematic narratives that instrumentalise women in the name of sustainable agricultural development. However, we also find other more transformative discourses that, in troubling the drivers of gender inequality and promoting shared responsibility for change, reflect a deeper awareness of feminist scholarship. In any effort to advance sustainable agriculture, further progress is needed to address the myriad ways gender pervades not just development settings but development institutions and donor nations, and contributes to the production of as well as responses to global A4D challenges.

Keywords: gender, agriculture, development, feminism, discourse

\section{INTRODUCTION}

Sustainable food systems rely on sustainable forms of agricultural production, where sustainability includes not just a long-term absence of known environmental harms but dynamic and thriving social and ecological relations respectful of diverse lives (Norton, 2005; Pretty, 2008). As Ben-Eli (2018) argues, genuine sustainability includes maximizing the "freedom and potential self-realization of all humans without any individual or group adversely affecting others." There is growing awareness that sustainable agriculture requires addressing forms of power and privilege within agricultural production and supply chains to include more diverse human voices and address structural issues (e.g., Faxon, 2017; Slätmo et al., 2017; Jerneck, 2018; Winter et al., 2020). In particular, gendered forms of social organization are deeply embedded across a variety of scales within food systems, at the household and community level and extending through to international organizations such as the Food and Agriculture Organization of the United Nations and the Global Forum for Rural Advisory Services (e.g., Zuckerman, 2007; Kangmennaang et al., 2017). However, gender has been neglected in discussions of agricultural sustainability 
(Slätmo et al., 2017) and gender inequality remains a significant barrier to the development of inclusive, genuinely sustainable forms of agriculture.

That said, approaches to and motivations for addressing gender inequality have been evolving. At the macro, global level, gender is increasingly visible on the agenda in international development. Goal five of the United Nations' 2015 “Sustainable Development Goals" is to "Achieve gender equality and empower all women and girls" (UN 2018). Yet, what this means is contested. Since the 1970s, feminist activists and scholars have sought to foreground women and gendered dynamics in development theory and practice, with mixed results (Benería et al., 2016). Also on the development agenda is agriculture, which has been "rediscovered" as a food security issue linked to civil unrest and climate change in the global South (PahlWostl, 2019). In the specific "agriculture for development" (A4D) sector women and gender are now a highly visible discursive presence. Contributing to this gender-agriculturedevelopment convergence is the fact that both gender inequality and agriculture are considered more prevalent in "developing countries" (World Bank, 2011). This mutual constitution of gender and agricultural development issues has been reinforced by a sense that efforts to implement the gender agenda into agriculture has, at least in terms of visibility, been a "resounding success" (Cornwall and Rivas, 2015). From scholarly work (e.g., Bahta et al., 2017; Zossou et al., 2017; Farnworth et al., 2018; Jerneck, 2018), including participatory action research (e.g., Kiptot and Franzel, 2012; McDougall et al., 2013; Kangmennaang et al., 2017; Kristjanson et al., 2017), to the extensive A4D practice literature (e.g., World Bank, 2009; FAO, 2013; UN Women, 2015), women and gender have become central to agricultural development initiatives.

However, what is pursued in $\mathrm{A} 4 \mathrm{D}$ in the name of improved gender outcomes in sustainable agricultural development varies widely. In particular, feminist critics and grassroots movements have challenged the implementation of the gender agenda by international organizations in ways that reproduce neoliberal policy frameworks, thus failing to take meaningful steps toward either gender equity or the development of sustainable food systems. It is therefore important to look critically at the intellectual underpinnings of "gender" interventions (Cornwall and Rivas, 2015), particularly as they pertain to globally dominant constructions of agriculture and food policy. As feminists have long argued, the problem is not just the inadequate inclusion of women, but an inadequate engagement with gender in development discourse and practice (e.g., Moser, 1989; Parpart et al., 2002; Benería et al., 2016). Because un-nuanced gendered approaches to development can exacerbate inequalities, reentrench forms of difference, or marginalize women in new ways, the assumptions and outcomes of gender initiatives require constant evaluation. Such vigilance is vital, if meaningful food systems transformation, from a gender perspective, is to be achieved.

In this paper we identify approaches to women and gender within prominent $\mathrm{A} 4 \mathrm{D}$ materials and consider how $\mathrm{A} 4 \mathrm{D}$ as a field of practice has incorporated longstanding feminist critiques of development. We provide cautions about problematic discourses, identify areas where progress is yet to be made, and point to how gender issues are being more genuinely integrated into $\mathrm{A} 4 \mathrm{D}$ research and praxis. In doing so, we examine how gendered discourses at the global level represent, and potentially inform, gender dynamics on the ground in agricultural contexts, in either transformative or limiting ways. Recognizing how gender as a concept is operationalized in $\mathrm{A} 4 \mathrm{D}$ is important in any effort to advance sustainable agriculture. We open with an historical overview of key debates around women, gender and agricultural development (section Gender in the Agricultural Development Literature), to provide a framework for the ensuing empirical analysis of how gender is discussed by major A4D organizations (section Gender in Agricultural Development Policy). We conclude in section Conclusions with observations about how $\mathrm{A} 4 \mathrm{D}$ can engage further with gender, in order to generate more inclusive and gender-equal sustainable food systems.

\section{GENDER IN THE AGRICULTURAL DEVELOPMENT LITERATURE}

Reflecting broader debates around gender and development, in the A4D literature gender features in two main ways: as an issue that development professionals encounter in the development setting, which is the main focus of approaches to gender in the agricultural development literature explored here; and as an issue internal to the development sector that in turn reshapes the context it is intervening in. We pick up this latter point regarding the need for a reflexive account of how gender norms are (re)produced in development organizations and the sector itself later in the paper.

The long history of agriculture as a development priority has seen an array of approaches to gender (Table 1), including various gender-blind and women- or gender-focused interventions. During the colonial era, gender-blind and male-biased A4D interventions largely excluded women (Korieh, 2001) while concurrently imposing a Western male-breadwinner model via technocratic programs designed to shift agriculture from a subsistence to commodity basis (Boomgaard and Hart, 2011). By prioritizing, for example, men's access to land for cash crop cultivation and farming inputs, colonial administrators consistently "undervalued the productive role" of women farmers (Boomgaard and Hart, 2011), while increasing women's reproductive labor by removing men from subsistence (Lado, 1992). In these ways, colonial processes of "agricultural development" insidiously redefined gender relations in situ, entrenching new forms of male dominance in the image of Western patriarchy.

Women rose to greater visibility in the 1970s with the rise of the Women in Development (WID) paradigm, which was designed to give greater recognition to women's roles in agricultural production and recognize women as legitimate farmers (not just "farmers' wives"). Epistemologically grounded in liberal feminist anti-discrimination discourse at a time when postcolonial and civil rights movements were on the rise (Bandarage, 1984; Tinker, 1990; Koczberski, 1996), the WID approach contested previous positionings of women 
TABLE 1 | Overview of main approaches to gender in agriculture for development.

\begin{tabular}{|c|c|}
\hline Approach to gender & Brief description \\
\hline $\begin{array}{l}\text { Gender } \\
\text { blind/gender-biased } \\
\text { approaches }\end{array}$ & $\begin{array}{l}\text { Implicit approach to development since early } \\
\text { colonial era that overlooks women and reinforces } \\
\text { unequal gender relations at multiple scales }\end{array}$ \\
\hline $\begin{array}{l}\text { Women In } \\
\text { Development (WID) }\end{array}$ & $\begin{array}{l}\text { Explicit recognition in international development } \\
\text { initiatives of the particular position and needs of } \\
\text { women in society }\end{array}$ \\
\hline $\begin{array}{l}\text { Gender And } \\
\text { Development (GAD) }\end{array}$ & $\begin{array}{l}\text { Explicit recognition of the need to address men, } \\
\text { gender norms and broader gender relations, not just } \\
\text { women, to cultivate more inclusive development }\end{array}$ \\
\hline Gender mainstreaming & $\begin{array}{l}\text { Recognition that gender is not an "add on" or } \\
\text { "special" topic but infuses all aspects of society and } \\
\text { needs to be mainstreamed in international } \\
\text { development work }\end{array}$ \\
\hline Intersectionality & $\begin{array}{l}\text { Approaches that understand gender as only one } \\
\text { axis of difference and experiences of gender } \\
\text { inequality as entangled with other forms of social } \\
\text { stratification along the lines of class, race/ethnicity, } \\
\text { age, ability, and LGBTQIA+ status, amongst others }\end{array}$ \\
\hline $\begin{array}{l}\text { Gender transformative } \\
\text { approaches }\end{array}$ & $\begin{array}{l}\text { Approaches that seek to tackle the structural root } \\
\text { causes of entrenched gender inequalities at multiple } \\
\text { scales, including gender norms and roles, rather } \\
\text { than merely responding to the symptoms of gender } \\
\text { inequality such structures produce }\end{array}$ \\
\hline
\end{tabular}

as economic dependents responsible simply for household nutrition and family planning (Chua et al., 2000). WID scholars and practitioners argued that colonialism, modernization and "gender-neutral" development oftentimes exacerbated existing inequalities, or even marginalized women in new ways (Tinker, 1976; Kabeer, 1994). This resonated with the broad, inclusive Beyond Farmers First movement that grew out of the postcolonial Farmer First model, which tried to invert the conventional view of male farmers as primary decision-makers and farming populations as deficient and passive recipients of development assistance (e.g., Scoones and Thompson, 1994). Farming systems research, feminist economics and rural sociology have highlighted further gendered aspects of the complex economics and relations in farm households, including how women's reproductive labor and other work is often essential to farm viability but overlooked and devalued (e.g., Sachs and Alston, 2010). Doss (2018) points out how women's agricultural labor, such as output marketing, is vital but excluded from standard agricultural productivity measures.

In response to these problems, women have been targeted as objects of recognition, inclusion and empowerment (Alkire et al., 2013; Cornwall and Rivas, 2015). Building on the broader rise of the women's movement and, in particular, the rise of the Commission on the Status of Women to complement and pressure the UN on women's human rights, the WID turn within international development promoted positive, affirmative projects for women as a "recognized constituency" (Kabeer, 1994), including the elimination of discrimination and establishment of Women in Development offices by many nations as part of their foreign aid work (Fraser, 1999). Although there were broad differences in strategy, with some NGOS and nations focusing on legal reform and legal literacy and others on social welfare, "the ultimate desire, then and now, is for women to be considered human, a diverse, multifaceted group with both common, and conflicting interests" (Fraser, 1999).

From a more instrumental perspective, the concept of "gender equality as smart economics" (introduced by the World Bank's 2012 World Dev. Report) has tried to progress the WID agenda by endorsing female participation as good for the economy, valuing women for their useful contribution to alleviating hunger, poverty and the disease burden via their contribution, for example, to household production and nutrition. Although it has been used to argue for decent work for womene.g., in Nigeria (Ola-David and Oyelaran-Oyeyinka, 2014)and aligns with a liberal feminist agenda (Tong and Botts Fernandes, 2018), many feminist critics have highlighted the limitations of such approaches. Smart economics has been criticized for instrumentally using women "for purposes that do not necessarily serve goals of wider gender equality" (Calkin, 2015; Benería et al., 2016). Similarly, the simple inclusion of women in rural community development programs has been critiqued as transposing gendered norms about women's disproportionate responsibility for social reproduction and care work from the private to the public realm (Little, 1997; Midgley, 2006), adding "community development" to women's workload and doing little to address the devaluation of feminized work such as raising children or chickens, which has traditionally been trivialized (Rai et al., 2014). Cornwall and Rivas (2015) critique the narrow notions of individual women's self-actualisation at work here, arguing that they replace the most fundamental element of empowerment-“changing power relations"-with individualized capacity-building. They also argue that failure to contest lines of power and privilege within a community obscures the relational aspects of empowerment, while target-oriented and measurement-dependent empowerment casts it as endpoint rather than a process (Cornwall and Rivas, 2015). As they explain, "although interventions such as legal changes, education policy or microfinance initiatives favoring women can be measured ... these should be seen as enabling factors or outcomes, but cannot be interpreted as proxies for empowerment" (Cornwall and Rivas, 2015).

Something of a response to such critiques, a broader Gender Dev. (GAD) approach arose in the 1990s. Central to the ongoing GAD approach is a focus on social relations of gender (not just women) and how these relations interact with other social dimensions. Moving away from WID's emphasis on women's participation and access, GAD places greater weight on understanding the different subject positions of women and men in any given social context (Koczberski, 1996). ${ }^{1}$ As Kabeer (1994) explains, this move toward GAD highlights "how the relations of class and gender mediate social realities, translating

\footnotetext{
${ }^{1}$ Scholars such as Chua et al. (2000) contest this opening up of the discourse to include men, arguing women as an oppressed group still require specific attention in development discourse and practice. They argue that to use the term "gender" "risks marginalizing women qua women" (Chua et al., 2000, p. 824, emphasis in original).
} 
broader processes of change into concrete gains and losses for different groups of women and men." A GAD approach encourages the exploration of economic and social complexities emerging from transformations within the agricultural sector driven by urbanization, environmental change and political economic shifts. One prominent issue is the "feminisation of agriculture" caused by males disproportionately migrating offfarm to seek paid employment in urban or industrial areas, leaving women to run family farm enterprises (Boserup et al., 2013). Results are ambivalent about the extent to which women are "empowered" by this agrarian change. Women's increase in farm responsibilities rarely comes with relief from domestic responsibilities or status enhancement (e.g., Bigler et al., 2017). Simultaneously, their ability to use migration as a "pathway out of poverty" tends to be constrained by gender norms, exemplifying how gender contributes to differentiating people's access to (post)agrarian livelihood options (World Bank, 2007; Holmelin, 2019). Access to, and the sustainability of, off-farm employment is also gendered, with women in sub-Saharan Africa, for instance, generally less able to access off-farm work and less able to retain its long-term if they do find it (Van den Broeck and Kilic, 2019). These issues leave many women more dependent on the natural resource base of agriculture, adding to their vulnerability to climate change.

Recognition of differences among women is highlighted by the theory of intersectionality that was first introduced by African American feminist Kimberlé Crenshaw to underscore the idea that the experience of multiple forms of oppression is "greater than the sum of sexism and racism [or other forms of discrimination]" (Crenshaw, 1989, p. 140). Intersectionality highlights the "inequalities, marginalisations and dominations that the interactions of gender, race, class and other systems of inequality produce" (Kantola and Lombardo, 2017). Key here is the word interactions. The focus is on how different oppressions work to exacerbate or alter the experience of one another and are therefore not merely additive. ${ }^{2}$ Rurality, poverty, and landlessness, for instance, interact in complex ways with femaleness to generate disadvantage (e.g., Levien, 2017). This is highlighted by scholarship underlining how agricultural women's vulnerability is exacerbated by deeper cultural factors such as the ongoing gendering and devaluation of their subsistence production. In Zambia, for instance, domestic food production is framed "as [just] 'reproduction' within capitalism rather than as a separate mode of production articulated with capitalism" (Leahy and Brown, 2016). Crucially, such production and associated "liminal" spaces and specieshome gardens, chickens-are typically devalued because they are feminized. While female producers can succeed regardless (e.g., Hovorka, 2006), commercial forms of production, spaces and species tend to be valued more highly by virtue of being masculinised, further limiting women's access to them as a result. Exemplifying such a "gendered agricultural imaginary" (Squier, 2010) is the way women's participation in Kenyan dairy markets is blocked by "gendered ideologies and norms that

${ }^{2}$ For debates around the utility of the term, see (Davis, 2008; Collins and Chepp, 2013; Kantola and Lombardo, 2017). ascribe masculinized meaning to cattle, milk, and commercial enterprise" (Tavenner and Crane, 2018). We begin to see, here, how gendered blockages in women's participation in agricultural production, or the valuation of such participation when it occurs, can obstruct the development of sustainable food systems. Moreover, this gendering of types of work is dynamic, shaped more by what women are associated with than the characteristics of an activity. For instance, in Malawi the rise of contract sugar farming has led to a "masculinization of farm management and ownership together with a feminization of labor" in an ideological as well as demographic sense; as women step in to do more farm labor they may become more empowered than they were, but not relative to the men doing farm management, with farm labor being simultaneously devalued thanks in part to its framing as women's work (Adams et al., 2019 , p. 282). One upshot of these gender dynamics is that gender-blind development initiatives, or even those blind to the reach of dominant masculinities, risk inadvertently exacerbating gender inequality.

Challenging the devaluation of subsistence agriculture and care work is the food sovereignty or "agroecology" movement. Defined in various ways and consisting of many variants, including some that are increasingly mainstreamed (FAO, 2018), this large and multifaceted movement contests the corporatised direction and control of the agro-food system and its systematic devaluation of, and violence against, peasants (smallholders) and environments in order to help advance a more genuinely sustainable agri-food system (Naranjo, 2011; Holt-Giménez and Altieri, 2012). Closely associated with neopopulist agrarianism, food systems perspectives (Francis et al., 2003; Ericksen, 2008) and the science of agroecology (which challenges conventional agricultural science with systems thinking, ecological insights and a focus on integral sustainability) (Gómez et al., 2016), it calls out the elite research and innovation system, reductionist interpretations of agricultural issues and the capitalist private property regime at the basis of industrialized agriculture (Beling et al., 2018; Portman, 2018). Core to its agenda is gender equality, not just because of the disproportionate effect of the above on women, but because of the resonance between its multifaceted agenda and ecofeminism, including the need to recognize the relational character of the world and revalue nature, care and local knowledges (Gómez et al., 2016; Figueroa-Helland et al., 2018; Portman, 2018).

In the broader literature, research into masculinities blossomed in the 1990s. Although scholars began to theorize ways it could inform development practice (Cornwall, 1997), 20 years later examinations of masculinity in development remain patchy, with most effort concentrated on the twin issues of gender-based violence and reproductive health (Wanner and Wadham, 2015). In the non-development literature, however, agriculture and rural masculinities has been a key topic (e.g., Brandth, 1995; Peter et al., 2000). A small amount of emerging research sits at the intersection of these fields. For example, Koczberski and Curry (2016) unpack how men's intergenerational farming relationships are evolving in Papua New Guinea, reshaping understandings of masculinity and privilege in PNG agriculture. 
Some research in development calls for new masculine norms that encourage men to take on more care work. The origins of this argument lie in contesting the assumption that the main impediment to women's equality is a lack of access and opportunities, thus should these impediments be removed, women will make the most of ensuing opportunitieswhile retaining their responsibility for multiple arenas of (re)production. As Chant and Sweetman (2012) explain, this assumption is unjust: "relying only on female populations even to guarantee business as usual, let alone transform the world, demands super-human sacrifices in terms of time, labor, energy, and other resources." Chant (2008) argues that there is a need to recognize and alleviate women's growing share of "the burden of dealing with" poverty and household responsibility by fostering "co-responsibility" through "the more active support of men, employers and public institutions in domestic labor and unpaid care work" Chant (2008). It is an idea that could be broadened beyond care-work to shared responsibility for community development and the devalued feminized areas of agricultural labor including those most closely involved in food production for domestic consumption.

To try to reduce some of those risks outlined above, practical and academic work striving to improve development outcomes in $\mathrm{A} 4 \mathrm{D}$ has progressively become more "gender sensitive" and adopted the WID approach of targeting women within extension services and beyond (Jaquette, 2017). This has included significant efforts by $\mathrm{A} 4 \mathrm{D}$ practitioners on the ground to redress barriers to women's participation, from altering mundane but crucial details such as workshop timing, to helping make their participation more culturally acceptable, to assisting female extension staff access resources (Charatsari et al., 2013; Ragasa, 2014; Agwu and Ogbonnah, 2015; Mudege et al., 2016; Quaye et al., 2019). More recently, there have been strong efforts to "mainstream" gender across agricultural development, in line with a shift to a GAD mindset and efforts in other agricultural contexts (e.g., Shortall, 2015).

Yet none of these moves have been accepted wholesale. Gender mainstreaming has especially been debated. Some feminists support the ideal but argue it is problematic in practice. For example, Acosta et al. (2019) found gender mainstreaming was "domesticated" in Ugandan agricultural and climate policy in a way that thwarted its radical potential. Others resist mainstreaming's shift away from women-specific interventions (Kantor et al., 2015). Ransom and Bain (2011), for instance, warn the rhetoric of gender mainstreaming "may be being used to legitimize a decline in focusing explicitly on women" in international agricultural aid projects. Moreover, others argue that the rush to operationalise a gender mainstreaming approach can overly focus attention on tools, indices and metrics. In A4D, the "Women's Empowerment in Agriculture Index" (WEAI) has become a prominent tool for development agencies to try to benchmark levels of gender inequality in a particular region in order to design appropriate development interventions (e.g., Alkire et al., 2012; 2013; Ragsdale et al., 2018). Although widely used across the sector and reported in academic work, the quantitative, survey-based approach to measuring women's empowerment sits uneasily alongside extensive feminist critique of the limits of quantitative approaches in capturing the women's lived experiences (e.g., Ramazanoglu and Holland, 2002).

Increasing women's access to and engagement with agricultural science via training opportunities is another common strategy in $\mathrm{A} 4 \mathrm{D}$. But significant gaps still remain. Mudege et al. (2017, p. 1,689) found in Malawi, for instance, that "negative stereotypical perceptions about women by their husbands and extension workers" continue to militate against women's ability to access to training and information in practice. Moreover, feminist scholarship has started to question the objective of expanding access to science because, while assisting some women, the associated celebration of (reductionist) agricultural science over alternative, local ways of knowing can disadvantage and devalue more agroecological and ecofeminist perspectives and women's local knowledge. Aguiari et al. (2017) argue in their analysis of the AWARD program (African Women in Agricultural Research and Development) that producing women scientists is not sufficient and instead "gender transformation must take place in the very values and dynamics of the places in which discrimination originates, and where gender inequality is repeated over time," which is to say in the symbolic structures that gender different knowledges in the first place.

The attempt to draw these factors together in discussions of international food sustainability-that is to say, women's participation in agriculture, the importance of valuing local knowledges and an awareness of the gendered challenges related to agricultural knowledge, science and technology (AKST) - can be seen in the 2009 International Assessment of Agricultural Knowledge, Science and Technology for Development Report, "Agriculture at a Crossroads." The report notes that "genderrelated patterns of resource access and control" are a key factor in the development of sustainable food systems (IAASTD, 2009), while also noting that these extend into the realm of AKST. Thus, technologically-focused solutions are inadequate without attention to gender, given that "agricultural development sometimes strengthens patterns that are unfavorable to women, such as male bias of the agricultural extension system in many countries" (IAASTD, 2009). Thus, the report attempts to marry AKST solutions to sustainability challenges in agriculture with a broader discussion of the need to radically rethink the goals and values of global agriculture. The result is a proposed paradigm shift that centers local knowledge of sustainable practices, and nests technological innovations within sustainable social and production systems.

Within the "Agriculture at a Crossroads" report, there is a particular emphasis on the ways in which governance and policy are a key enabling factor in women's access to productive resources. This focus is reflective of the broader human rights agenda at the intersection of "women" and "agriculture." For example, "General recommendation No. 34 (2016) on the rights of rural women," from the Committee on the Elimination of Discrimination Against Women, centers the establishment of "enabling institutional, legal and policy frameworks" to ensure that policy related to agriculture, development and natural resources is "gender-responsive" (CEDAW, 2016). Similarly, the Food and Agriculture Organization's "Voluntary Guidelines on 
the responsible governance of tenure of land, fisheries and forests in the Context of national food security" underscores the importance of participatory processes that encompass both men and women in the establishment of governance mechanisms for land tenure, again foregrounding the importance of resource access to create more gender-equal agricultural and food systems (FAO, 2012). While this gendered focus within many of the relevant human rights instruments and documents provides an important framework for generating a more gender-just future within agriculture and food systems more broadly, it is worth acknowledging the longstanding feminist debates surrounding the utility of the international human rights regime for advancing the feminist cause (e.g., Charlesworth, 1995). Such instruments provide a useful tool with which to push for gender equality within global food systems, yet imperfections remain-not least in the fact that such documents can be employed in the pursuit of ideologically diverse agendas. We explore some of the various ways in which the gender agenda manifests in $\mathrm{A} 4 \mathrm{D}$ in our analysis below.

Importantly, despite these criticisms, human rights discourse and documents (rightly) remain at the heart of development work. Development work rests on a shared conception of human dignity and the universality of human rights, coupled with states' obligation to address rights violations and further international cooperative work. Feminist (and broader critical theory) understandings of structural change in the development sphere are grounded in the interconnected web of rights: from the right to equality before the law, to women's rights to equal opportunities in political and public life with men, to the right to food and shelter, and many more. A4D embodies a vast number of these underlying principles, and thus cannot be decoupled from a rights framework. In fact, as Carella and Ackerly (2017) argue, ensuring a rights-based approach to Gender Dev. is crucial to maintain a politicized understanding of gender in the development sphere, and retain a focus on power in development.

Lastly, it should be noted that the practical and political value of "gender transformative" strategies relative to more incremental "gender sensitive" or "gender responsive" strategies is a topic for debate among development practitioners (Collins, 2018). Some argue that long-term social change requires a multilevel approach involving both. Beuchelt and Badstue (2013), for example, assert that gender-responsiveness usefully accounts for the specific needs of groups of women and men in situ, while gender-transformative approaches usefully "seek to examine, question, and change gender norms, roles and power imbalances" more broadly.

Having provided an overview of historical and contemporary feminist analyses of gender in $\mathrm{A} 4 \mathrm{D}$, we turn now to practical and policy documents about gender in the $\mathrm{A} 4 \mathrm{D}$ sphere. Our focus is on how those working in $\mathrm{A} 4 \mathrm{D}$ have responded to the multiple messages about women and gender that have come not just from feminist academics, but the "traveling circus of experts-gender technocrats touting a new kind of export product, whose brandname has shifted with the decades" (Mama, 2007). We examine how the associated policy initiatives in $\mathrm{A} 4 \mathrm{D}$ do or do not integrate the various approaches and recommendations outlined above.

\section{GENDER IN AGRICULTURAL DEVELOPMENT POLICY}

\section{Analytical Approach}

Practitioner and policy texts are a crucial part of the discursive environment in development. Yet the ambiguous status of practitioner and policy texts as both literature and data means that they are too often neglected in social research, including in agriculture, where most empirical research is firmly focused on "the ground," leaving unexamined the influential discourses and policies that shape it. In keeping with the more relational, systemic thinking that has emerged in both feminism and agriculture, we want to draw attention to the discursive environment of $\mathrm{A} 4 \mathrm{D}$. In particular, we consider key documents by $\mathrm{A} 4 \mathrm{D}$ agencies and other major players. A purposive sampling (Guest et al., 2006) approach was used to identify key organizations and documents for analysis. Firstly, the six key organizations that were targeted were chosen through a stakeholder analysis performed as part of the broader project that this paper forms part of. This entailed immersion in the scholarly and development literature pertaining to A4D, as well as identification of leading organizations via key informant interviews for the broader project. Through this, we paid close attention to those bodies featured prominently within the scholarly literature or discussed by our stakeholders, as well as the use of targeted search terms related to A4D in an internet search engine to identify leading A4D practitioner organizations. Websites were then analyzed to identify leading bodies and map connections between organizations. While we do not claim that the organizations we analyse are representative of the entire $\mathrm{A} 4 \mathrm{D}$ landscape, they do constitute several of the major players. Through this process, the following six organizations emerged as leading figures in gender research and praxis in the agricultural development arena: global policy groups (1) the FAO, and (2) World Bank; research and development networks (3) the Consultative Group on International Agricultural Research (CGIAR), and (4) the Global Forum for Rural Advisory Services (GFRAS); and major funding organizations, (5) the US Government international aid body (USAID), and (6) philanthro-capitalist organization the Bill and Melinda Gates Foundation (B\&MGF). In including the latter we respond to Shaw and Wilson (2020, Online First) call in this journal for further research into the gendered assumptions of B\&MGF's global policies.

Our goal is to recognize that, rather than being considered separate to academic discussions, documents by these groups are linked to the academic world via a two-way flow of ideas and their influence on the funding available for subsequent knowledge production. While it is beyond this project to examine the political economic relations or social linkages between these groups and academia, as a first step we examine the extent to which their policies and assertions are responding to insights and concerns in the feminist literature.

A selection of documents was purposively chosen to provide an overarching view of each organisation's dominant narrative around gender, including: the "gender" websites of each body and relevant documents featured therein; their key gender policy 
document; and recent strategies or reports specifically pertaining to agriculture and gender. This process yielded six "gender" webpages and 16 further strategy documents and reports. Once the sample had been collected, we conducted a feminist critical discourse analysis (feminist CDA) of their contents, aided by the use of NVivo qualitative analysis software. Critical discourse analysis more broadly aims to understand the ways in which language, and the narratives it creates, perpetuates or disrupts dominant power relations (Fairclough, 1995; Punch, 1998). It distinguishes itself from other forms of textual analysis due to the fact that it looks beyond a narrow, linguistic frame to include factors such as the context within which the information was placed, how it was framed and the implied tone of the piece (van Dijk, 1991; Deacon et al., 1999). In the context of this study, this may include, for example, the location of text within the website or report. Contextual factors, including the political milieu, are drawn on to ensure a more accurate picture of the text itself, thus guaranteeing that the words are not viewed in isolation, but rather presented as a cultural product, the content of which is contingent on external influences (van Dijk, 1991; Deacon et al., 1999). It is for this reason that we situate our analysis within the broader historical trajectory of women and gender in a development context. Feminist CDA more specifically hones in on the ways in which language can produce, reproduce or otherwise buttress patriarchal forms of social organization or ways of seeing (Lazar, 2005). It is with this "gendered lens" that we approach the analysis of practitioner data below.

It should be noted that feminist CDA is not a form of content analysis, in that it does not seek to delineate mutually exclusive and replicable coding categories that are recorded in a coding schema. Rather, feminist CDA seeks to identify and record dominant narratives that emerge inductively from the data, while also accounting for counter examples, absences or exclusions. In our analysis, we focused specifically on the emergence of discourses that either actively incorporated or responded to feminist concerns, or that perpetuated problematic narratives instrumentalising women and girls. The use of NVivo software facilitated this identification and recording of key themes, alongside "deviant cases" (Silverman, 2001), by allowing the researchers to record themes and annotate the data. The use of software also facilitated key word searches, such as "masculine" and "masculinity," to accurately capture the prevalence of core concepts across the dataset.

At one level, the results reveal a similar pattern to that found by Wilson (2015) in her analysis of representations of gender issues in various areas of development policy. She concludes that "elements of feminist thinking" have been appropriated into contemporary development policy, but that such incorporation has been selective, bolstering rather than challenging a neoliberal approach. Our results also resonate with empirical studies in A4D that point to partial gains for women's empowerment (e.g., Waltz, 2016; Bain et al., 2018). By studying high-level policy documents, our study contextualizes these grounded analyses and points to one reason for the partiality of success they observe. At the same time, we also point to more promising trajectories.

\section{Women as a Development Tool}

As discussed above, attending to women within A4D is not new. Discourses regarding the centrality of women to development and debates about their role within it have existed since agricultural development became a strategic focus during the colonial era (Kabeer, 1994). To include women in formulations of development is therefore neither new nor necessarily progressive in orientation. Attending to women's place in development, or seeking to bring them "in" to development practice, cannot be the only goal of gender and development. Ongoing critical attention is required to assess how women are incorporated into discourses of development. In the "gender" literature produced by key agricultural development institutions, there is a persistent focus on women's access and resources in conjunction with an ongoing adherence to the concept of "smart economics." Despite extensive critiques made by scholars over decades revealing the limitations of these approaches, the "stickiness" of such formulations of women and gender in development is notable.

Taking as a case study the document "Creating GenderResponsive Agricultural Development Programs" (The Bill and Melinda Gates Foundation, 2012), produced by the Bill and Melinda Gates Foundation (the B\&MGF), women's role in agriculture is represented as the fulcrum on which economic development turns. The document provides an overview of the B\&MGF's gender strategy in the agricultural domain and is sparsely populated by text, with visual materials notably foregrounded. The document asserts that “ignoring a woman's role in agriculture has consequences for the success of our work" (The Bill and Melinda Gates Foundation, 2012) and states that "households are less productive," before going on to identify predicted yield increases were women farmers to obtain "critical knowledge, skills, and assets" (The Bill and Melinda Gates Foundation, 2012). Further consequences outlined in the document include lower rates of technological adoption amongst women and poorer household nutritional outcomes.

Several critiques can be made here. Firstly, in locating women's roles in agriculture in terms of whether the B\&MGF can create "successful" programs, the document represents a technocratic, modernizing model of success and participates in a self-serving rhetoric. This positioning mirrors Chant and Sweetman's (2012) argument that while claims to the wideranging benefits of investing in women and girls as agricultural producers may be correct, "it is imperative to ask whether the goal of female investment is primarily to promote gender equality and women's empowerment or to facilitate development on the cheap and/or to promote further economic liberalization." These questions are important, because the win-win situation presented by development institutions may belie a truth that sees women progressively more burdened with the responsibility of supporting increasingly precarious households and communities (Chant, 2008, 2012; Chant and Sweetman, 2012).

Secondly, in centring the productivity of households as the primary concern of women's agricultural labor, the document buys into heavily critiqued discourses which present unlocking the "potential" of women-as-producers as key to solving a variety of developmental challenges. As described above, while 
such "smart economics" is endorsed by liberal feminism, other feminists critique it for "seek[ing] to use women and girls to fix the world" (Chant and Sweetman, 2012) by integrating them into masculinised systems of production and consumption without addressing structural constraints or contesting the social construction of agricultural production and labor (Elson, 2012). Aiming to "make women more like men," "smart economics" suggests that women's increased agricultural productivity, profitability or market access promotes and even constitutes gender equality. Feminist scholars have repeatedly debunked the linearity of this association, pointing particularly to the ways that economic development can increase gender disparities (e.g., Menon and Rodgers, 2009).

The B\&MGF document calls on readers to support genderaware agricultural programs, stating, "together, we can support opportunities that ensure that women farmers are meeting their potential, contributing to sustainable productivity, and driving poverty reduction and hunger alleviation" (The Bill and Melinda Gates Foundation, 2012). Women here are positioned as not meeting their potential, while the principal benefits of such potential are defined in terms of productivity, economic gains and hunger reduction. This deficit narrative begins with lack, proceeds via solutions structured around access structured according to a masculine paradigm, and justifies itself with regards to non-gender-justice-related gains, even gains not couched in terms of the target beneficiaries (women farmers).

Problematic liberalist narratives are further reflected in a Science article by Melinda Gates that positions "women and girls as engines of development" because they are more likely to reinvest income in families and communities (Gates, 2014). Even if this is true, placing this moral burden and responsibility for development "success" on women while not challenging the idea that men are "unreliable" development subjects reinforces constraints on women.

Narratives about "smart economics," and their frequent counterpart "women's empowerment equals access," are identifiable across all six organizations in the dataset. Language around "unleashing" the power of women and girls is used by multiple organizations. While no doubt these intentions are genuine and do aim to improve real problems such as lack of decent employment opportunities for women, the increase in women's power that is imagined to result is positioned not as a righting of a deeply entrenched wrong but instrumentally as a means to "yield enormous dividends that help make whole societies more resilient and more prosperous," to use a World Bank example (Klugman et al., 2014). This supports Cornwall and Rivas's (2015) argument (discussed above) that "women's empowerment" in development discourse has been hollowed out into "a familiar series of tropes" whereby the "intrinsic value of women's empowerment" is touted, "before proceeding to the real business at hand ... harnessing the power of billions of women workers and their transformative economic effects as the producers and consumers who will drive growth." The prominence and pervasiveness of discourses that position women as an untapped resource, waiting for access to market production, fail to respond to almost 40 years of critique from scholars and practitioners alike.

\section{Recognizing Difference Through Intersectionality}

Of the six organizations analyzed here, more recent work by CGIAR appears to do the best job of escaping hollow discourses of "smart economics" or narrowly focussing on women's resource access. Although such discourses exist within CGIAR's materials, alongside these are more complex engagements with structural aspects of gender inequality and an attempt to envision transformational and participatory approaches to change. However, at the other end of the spectrum, CGIAR's approach risks fragmenting identities into endless subjectivities, undermining the potential for structural critique. This radical deconstructionism is evident in "Making Sense of 'Intersectionality': A Manual for Lovers of People and Forests" (Colfer et al., 2018), produced by the CGIAR subsidiary CIFOR. The document laudably seeks to engage with the idea of "intersectionality," demonstrating a rare institutional willingness to do so. It also acknowledges the complexity of power relations in particular situations, while systematizing and consolidating this knowledge for better, more equitable forest management. This is no small task, and its goals reflect and engage with feminist theorizing regarding what good development work ideally looks like (e.g., Chant and Sweetman, 2012; Cornwall and Rivas, 2015). It also represents the only significant attempt to consider queer perspectives within our dataset, incorporating the intersections of diverse genders, sexes and sexualities in its analysis. Work on sustainable agriculture in the US, for example, highlights the need for a more relational conception of agriculture that addresses the ways in which some aspects of contemporary agriculture continue to harm women and queer farmers and limit sustainability (Leslie, 2017; Leslie et al., 2019). The CIFOR booklet begins to open up these questions in the $\mathrm{A} 4 \mathrm{D}$ sphere.

However, in its attempt to account for diverse lived realities, the booklet also risks fragmenting identities to the point that important categories-including gender-fade from view. It frequently underscores that individuals can be both positively and negatively impacted due to various facets of their identity. For example, the authors stress that "in reality, of course, each individual posits many intersecting identities, which in a given situation and context may be sources of both privilege and oppression" (Colfer et al., 2018). While this is true, the issue is whether emphasizing this point is politically relevant in a document designed to assist "those interested in more effectively incorporating gender and other equity concerns into forest management" (Colfer et al., 2018). A highly individualistic approach risks falling into a relativist ontology that emphasizes individuals' complex and shifting identities at the expense of structural factors, making questions of equity between groups in very different structural positions difficult to discern. Although the booklet foregrounds gender, its focus on how individuals' "many intersecting identities" both benefit and constrain them arguably dilutes the political power of a feminist analysis. While some feminists have actively sought to complicate the category "woman," social science analysis relies on some level of abstraction in order to identify patterns of power and marginalization between social groups (Healy, 2017) and activism relies on a notion of political collective (Benhabib, 1992). 
Adding to these risks is the way the authors point out that "feelings of inferiority and lack of self-confidence are not, of course, limited to those at the bottom of the social heap. It is quite possible for relatively elite persons to suffer similarly" (Colfer et al., 2018). Again, this is true, but implying that elites' lack of self-confidence is comparable to other forms of inequality (e.g., based on race, class, caste, and ability) without clarifying how it is materially different undermines the broader purpose of the document and detracts from its aim of tracing the complex intersecting lines of disadvantage that must be accounted for in agricultural research and development in the forest sector.

To its credit, the CIFOR booklet does demonstrate some awareness of these risks and advocates for the strategic use of categories to interpret and respond to social landscapes in development. The authors point out that the endless deconstruction of categories:

... risks ignoring or even denying inequities along gender, caste, class or ethnic lines that marginalize certain people and not others. Dissolving such categories does not erase discriminatory structures and practices. It also raises questions about collective mobilization against discrimination. How do we mobilize against "racism" or "patriarchy" if we question the relevance of "race" or "gender"? (Colfer et al., 2018).

Drawing on McCall (2014), the authors suggest a balance must be found between the "danger" of "externally defined" categories, which may be reductive, and the political impotence of an anti-categorical approach (Colfer et al., 2018). Researchers at CIFOR are clearly attempting to navigate this balance between homogenisation and radical relativism. The critiques here merely point to occasions when this balance is perhaps tilted unproductively toward relativism.

What is interesting when juxtaposing the two discourses explored thus far-at one end of the spectrum, the instrumental use of women and at the other, the attempt to account for the complexity of lived difference-is the ways in which they diverge and converge. At the instrumental end, the homogenized global woman is an unproblematised and uncomplicated figure who is positioned as the savior of development. At the other, the category "woman" is rejected as a blunt tool, replaced instead with fragmented and shifting identity categories. One is understood as politically conservative, technocratic, lacking in social awareness and unquestionably bound to neoliberal market ideology (Elson, 2012). The other is conceptualized as progressive, alive to social possibilities and complications, and resistant to dominant forces of politics and capital (Cornwall and Rivas, 2015).

Ironically, however, these divergent analyses almost come full circle at certain points. The instrumental approach sees individual women as targets of development and individualizes the responsibility for positive outcomes; if women are given the resources, failure is personal. The fragmented identities approach almost resists categorization to the extent that the individual is the only pure category, emphasizing each individual's personal perception and emotions. In the CIFOR report, this approach is epitomized by a description of changing social norms for young Nepalese women. Educated Hindu women are described as existing within an evolving social space where opportunities to contest limiting gendered practices are emerging. Yet women in this group who do not harness these opportunities are presented as failing to "resist the culturally constructed, gendered idea of their bodies as 'polluted"' (Colfer et al., 2018) or even potentially being "invested" in their "own subjugation" (Nightingale, 2011, Colfer et al., 2018, p. 16). The irony is that this individualization feeds into a neoliberal economic lens. If individuals belong to multiple identity categories that are fluid, shifting and given different meaning in different contexts, then each individual has a unique relationship to the market. This configuration reflects the rational actor, market individualism and self-reliance of neoliberal ideology (Cheshire and Lawrence, 2005). The lack of attention to structure and the individualization of responsibility and reward in both these examples, at either end of the ideological spectrum, represent interesting-and concerning-convergences.

\section{Participatory Approaches}

Despite ongoing debates surrounding the utility of participatory approaches to development (Cook and Kothari, 2001; Kawarazuka et al., 2017), critical scholars tend to identify carefully planned and implemented community participation as a vital spoke in the Gender Dev. wheel (Koczberski, 1998; Kawarazuka et al., 2017). A commitment to meaningful and reflexive participation is evident in the practitioner documents we sampled. For example, the GENNOVATE research initiative from CGIAR (2018) includes a significant focus on participation across different social groups:

In discussion groups and individual interviews, more than 7,500 rural study participants of different socio-economic backgrounds and age groups reflect on and compare local women's and men's expected roles and behaviors-or gender norms - and how these social rules affect their ability to access, adopt, adapt, and benefit from innovations in agricultural and natural resource management (CGIAR, 2018).

Here we see an attempt to understand the local contexts (the project works with 137 rural communities globally), with a commitment to going beyond community gatekeepers or relying on pre-existing NGO knowledge about locations by gathering input from locals who cross-cut societal groupings. The project website emphasizes the importance of accurate "contextually grounded evidence" of the social context of development, in order to ensure CGIAR can understand who their "target beneficiaries" are and therefore design meaningful programs and ensure accountability to those beneficiaries (CGIAR, 2018).

This acknowledgment that development practitioners must (1) be accountable to communities where they work-and especially marginalized members; (2) be equipped with accurate understandings of local power structures and dynamics; and (3) engage community members who cross-cut those societies, begins to address issues that critical scholars identify as key to effective participation. It resonates with Chua et al.'s (2000) assertion that forms of inequality and the relationships between inequalities are "locally specific, historically contingent, shifting, and enmeshed." How these principles are enacted on the ground and the extent to which meaningful self-assessment is 
undertaken by CGIAR will determine the extent to which this participatory research contests dominant power relationships. Sumberg et al. (2013) warn that the shift toward participation and empowerment has been largely discursive rather than material, and development institutions and projects generally remain hierarchical and modernist in alignment. As such, a closer evaluation of how gender-inclusive participation operates in practice is required to assess its effectiveness in accounting for or challenging power and privilege. Furthermore, participation is not an end in itself and its gender outcomes must be scrutinized.

\section{Gender as Relational, and Accounting for Masculinities}

Chant and Gutmann (2002) assert that although men "have always been present, involved, consulted, obeyed and disobeyed in development work," men "as a gendered category" have not been substantively incorporated into development programs. Our analysis supports this conclusion. Across our dataset, the terms masculine, masculinity or masculinities appear only 20 times in over 1500 pages. Further to this, the word "men"-although more common-often appears in generalized statements regarding "women and men," usually with minimal or no information unpacking the relations of power involved or the role that men and masculinities might play in Gender Dev. processes. This reticence in $\mathrm{A} 4 \mathrm{D}$ to address men as gendered is perhaps understandable. What is needed is a complex balancing act taking into account men's gendered vulnerability, power relations between groups of men, masculinity's hierarchical position over femininity (and in many cases, men over women), alongside the importance of men's involvement in development interventions (Chant and Gutmann, 2000; Wanner and Wadham, 2015). Moreover, dynamics shaped by the legacy of colonialism which position men in the global South as "feminized" and "inferior" to Western configurations of masculinity further complicate the navigation of masculinities (Mies and Shiva, 1993; Smith, 2005).

That said, there are signs that "men-streaming" within A4D research and practice is slowly becoming increasingly visible and sophisticated. In its report "Gender Mainstreaming in Agricultural Value Chains: Promising Experiences and the Role of Rural Advisory Services," GFRAS begins to engage productively with these questions. Besides acknowledging women as "a marginalized population in many contexts in comparison to men," it underlines the necessity of understanding "men's roles and activities" if gender programs are to be effective (Poulsen, 2016). The report also notes that "there are men in many contexts who are also vulnerable and marginalized" and underscores the utility of "engaging as many people as possible in discussing gender roles, marginalization, and vulnerability" (Poulsen, 2016). This approach is cognisant of some of the tensions and dilemmas outlined in the masculinities literature: the need to engage men (as gatekeepers) in gender equality, as well as the recognition of men's vulnerability and hierarchies between masculinities, while holding firm to the fact that women generally remain disadvantaged.

\section{Gender Norms and the Idea of "Co-responsibility"}

The challenging of gender norms and a shift toward coresponsibility within and beyond communities can be seen in the work of GFRAS. In their Good Practice Note, "Involving Men in Nutrition" (Otieno et al., 2016), GFRAS points to the fact that men are often prioritized in food distribution, with negative health outcomes for women and children. From here, however, the note asserts that involving men in challenging this trend is crucial, stating:

Integrating men in nutrition initiatives helps turn this situation around. By virtue of their power and privilege, men are in a prime position to tackle malnutrition in their own homes and in the broader community. In many households and communities, men make key decisions about what to grow and which animals to raise. They often decide what to sell, how much to store, and what foods to buy. However, many initiatives target women and girls, and ignore men. Women may learn a lot from courses on good nutrition, but excluding men means that women may not be able to act on their improved knowledge. Men may feel angry because their own nutritional needs are ignored (Otieno et al., 2016).

In keeping with Chant's call for co-responsibility above, the note articulates the importance of joint responsibility for family nutrition, alongside an inclusive approach from development practitioners. In identifying ways in which men as well as women shape nutritional choices, and in acknowledging the gendered relationships structuring these dynamics, the GFRAS note considers the subject positions of both women and men. It advocates co-responsibility by presenting women and men in combination as accountable for choices regarding food and nutrition and acknowledges the importance of "communitywide change", given individuals are "embedded in wider structures that condition their behavior" (Otieno et al., 2016). This emerging discourse regarding the accountability of men and women usefully challenges prevailing gender norms and represents a welcome step toward implementing the concept of co-responsibility.

\section{Toward Gender Transformative Change?}

Perhaps surprisingly, the "Gender in Agriculture Sourcebook," led by the World Bank with the FAO and the International Fund for Agricultural Development, demonstrates a high level of engagement with gender-transformative approaches. Gendertransformative work is touched on in the Sourcebook overview (World Bank, 2009) and repeated frequently throughout the document (World Bank, 2009). In a section on "Gender and Agricultural Livelihoods," various routes to creating gendered change are outlined, including those that are:

(1) sensitive to gender differentials, for instance, by making sure that women in the agricultural sector do not lose out in the reform process; (2) gender specific, that is, by addressing specific needs that differ between men and women engaged in agriculture; (3) empowering to women, for instance, by making provisions for affirmative action and creating more opportunities for rural women's participation in political processes; or (4) transformative, 
for instance, by attempting to change prevalent attitudes and social norms that lead to discrimination against rural women (World Bank, 2009).

The document goes on to examine how such strategies can be employed at multiple levels to both strengthen agricultural governance and reduce gender inequality.

It should be noted, though, that the "Sourcebook" is no beacon of feminist enlightenment. Although repeatedly engaging with gender-transformative development concepts, incremental efficiency approaches still pervade the document. The prevalence of the market (evident in the emphasis on finance products as a route to women's empowerment), shows that the economic doctrine underpinning the World Bank's approach to gender has not significantly altered, despite feminist critiques. Women remain positioned as "the key to food security for their households" (World Bank, 2009, emphasis in original)-perhaps unsurprising given feminists' ongoing critiques of World Bank publications (Elson, 2012; Scheer et al., 2016). Nevertheless, that a significant World Bank publication engages extensively with the concept of structural barriers to gender equality and endorses transformative means to creating positive social change suggests that this concept is becoming more "mainstreamed" in A4D. Whether this leads to improvements in practice on the ground requires ongoing evaluation.

\section{CONCLUSIONS}

Women have long been targeted by development interventions but not in a way that many contemporary feminists would consider progressive. In response to their criticisms over decades, a broader "gender agenda" is now emerging in A4D and discussions about sustainable agriculture more broadly. Concepts from critical development and gender studies are being more genuinely incorporated into practice. Recent projects from the CGIAR and GFRAS, for example, illustrate efforts to conceptualize gender as relational, to understand the importance of bringing men "in" to projects designed to reduce gender inequality, to promote whole-of-community responsibility for positive change, and to seek structural, long-term transformation of unequal institutions. While further evaluation is required to assess how these discourses are translated into on-ground programs, and how ideas flow between practice, policy and academia, the engagement with feminist and critical theory by key A4D organizations in their practice literature that we have identified here is impressive.

That said, our analysis also suggests that key international A4D organizations still frequently present arguments that instrumentalise women for broader development gains. Such appropriation of gender language into the service of mainstream development goals can increase the burden of responsibility on women to "fix" various development problems, eroding the radical potential of GAD (Cornwall and Rivas, 2015). A focus on individualized capacity-building at the expense of collective mobilization around root causes of inequality is liable to reproduce the gendered status quo and further reentrench disadvantage.
There is a need to address these ongoing weaknesses in the gender agenda in A4D to help generate genuinely sustainable agri-food systems. Moreover, other emerging challenges demand attention from scholars and practitioners alike. We pose five here. First is examination of gendered norms and meanings in the many other development arenas that are increasingly intersecting with $\mathrm{A} 4 \mathrm{D}$ - such as sustainability, health, water, food systems, land use planning, ICT and finance-and analysis of how these are affecting gender matters in $\mathrm{A} 4 \mathrm{D}$. Second is work on how the production of development challenges in $\mathrm{A} 4 \mathrm{D}$ (and beyond)-including environmental degradation, resource scarcity, climate change and land dispossession driven by urban settlement and the extractive sector-reflects underlying gendered relations, identities and symbolism. This points to a need for both more political economic analyses (e.g., Levien, 2017) and poststructural feminist analysis (e.g., Faxon, 2017), including critical analysis of proposed causal relations, notably gendered discourses about global population increases relative to agricultural carrying capacity (see Hendrixson et al., 2020, Online First; Shaw and Wilson, 2020, Online First).

Third, scholarship and policy that shifts from viewing gender in $\mathrm{A} 4 \mathrm{D}$ as a mere sub-topic or isolated factor to understanding it as a window onto fundamental development issues such as environmental degradation, inequality, citizenship and contested futures is also needed. To use liberal lexicon, feminist analysis is an "under-utilized tool" in development work.

Fourth, is the question of gender within development organizations, including those focused on research and extension in sustainable agriculture. Not only is this of importance for (female) staff in such organizations-and empirical work could usefully explore this-it is of importance for women around the world affected by research and development projects. Traditionally and today, A4D is led by large Western democracies with significant modern agricultural sectors. Such modern agriculture is deeply masculinised. For example, in Australia, where there is a strong focus on professionalizing agriculture, the sector is characterized by a marked marginalization of not just women but anything relatively feminine in agricultural occupations, science and positions of authority (Lockie, 2000; Pini, 2005). A similar ruralised masculinity is evident in the US and Europe, where-mediated by occupation, class, sexuality, race and place, among other factors (Leap, 2017) there has long been pride and confidence in a certain assertive mode of maleness (Heggem, 2014; Gahman, 2015; Katherine, 2018). Given the international agricultural research and extension landscape remains strongly shaped by Anglo male scientists and the "big men" of philanthro-capitalism (Berman, 1983; Ekbladh, 2011; Antle et al., 2017), it is important to consider whether and how the exportation of Western agricultural knowledge also exports problematic gender norms and relations, and associated attitudes to the environment.

That brings us to the final new area of research to note, which is analysis into how shifts in $\mathrm{A} 4 \mathrm{D}$ institutions and structures-such as the move to replace the Research, 
Development and Extension approach with alternatives such as Agricultural Innovation Systems, private farm advisors and ICT based services-are affecting gender relations on the ground (e.g., Masika and Bailur, 2015; Devaux et al., 2018). Do they, for example, allow farm women to bypass male gatekeepers, or do they generate new bastions of male farmerscientist privilege?

Meaningfully accounting for gender is multifaceted and complicated. Our analysis indicates that gender is on the agenda in $\mathrm{A} 4 \mathrm{D}$ and progress is being made. At the same time, the "stickiness" of market-oriented and instrumental approaches to women is notable and existing narratives around Gender Dev. tend to only reveal part of the agricultural development story and eschew the structural drivers of the problems being addressed. Arguably only some feminist critiques are flowing from academia to policy and practice. There is thus a need to keep gender on the $\mathrm{A} 4 \mathrm{D}$ agenda and to progress transformative new approaches in $\mathrm{A} 4 \mathrm{D}$ and beyond, appreciating that the sustainable agriculture and development sector is part of what requires examination. Lastly, the flows of ideas between policy and practice on the one hand and academia on the other beg the question of what critiques and insights academics such as ourselves need to take heed of from the world of policy and practice, including the strategies of women in their everyday lives.

\section{REFERENCES}

Acosta, M., van Bommel, S., van Wessel, M., Ampaire, E.L., Jassogne, L., and Feindt, P.H. (2019). Discursive translations of gender mainstreaming norms: The case of agricultural and climate change policies in Uganda. Women's Stud. Int. Forum 74, 9-19. doi: 10.1016/j.wsif.2019.02.010

Adams, T., Gerber, J.-D., and Amacker, M. (2019). Constraints and opportunities in gender relations: Sugarcane outgrower schemes in Malawi. World Dev. 122, 282-294. doi: 10.1016/j.worlddev.2019.05.029

Aguiari, S., Nkwake, A., and Mentz, M. (2017). Beyond the double gender gap in science and agriculture: Is there space for feminist-inspired transformation within AWARD? J. Gend. Agricul. Food Secur. 2, 106-124. doi: 10.22004/ag.econ.262298

Agwu, A.E., and Ogbonnah, E.E. (2015). Access and use of information communication technologies by women staff of public extension service in the north central zone of Nigeria. Agricult. Inform. Worldwide 6, 18-24.

Alkire, S., Meinzen-Dick, R., Peterman, A., Quisumbing, A.R., Seymour, G., and Vaz, A. (2012). IFPRI Discussion Paper: The Women's Empowerment in Agriculture Index. Washington DC: International Food Policy Research Institute. doi: 10.35648/20.500.12413/11781/ii033

Alkire, S., Meinzen-Dick, R., Peterman, A., Quisumbing, A.R., Seymour, G., and Vaz, A. (2013). The women's empowerment in agriculture index. World Dev. 52, 71-91. doi: 10.1016/j.worlddev.2013.06.007

Antle, J.M., Jones, J.W., and Rosenzweig, C.E. (2017). Next generation agricultural system data, models and knowledge products: introduction. Agricult. Syst. 155, 186-190. doi: 10.1016/j.agsy.2016.09.003

Bahta, Y.T., Strydom, D.B., and Donkor, E. (2017). Microcredit and gender empowerment: policy implications for sustainable agricultural development in Eritrea. Dev. Pract. 27, 90-102. doi: 10.1080/09614524.2017.1259393

Bain, C., Ransom, E., and Halimatusa'diyah, I. (2018). "Weak winners" of Women's empowerment: The gendered effects of dairy livestock assets on time poverty in Uganda. J. Rural Stud. 61, 100-109. doi: 10.1016/j.jrurstud.2018.03.004

Bandarage, A. (1984). Women in development: Liberalism, marxism and marxist feminism. Dev. Change 15, 495-515. doi: 10.1111/j.1467-7660.1984. tb00194.x

\section{DATA AVAILABILITY STATEMENT}

The raw data supporting the conclusions of this article will be made available by the authors, without undue reservation.

\section{AUTHOR CONTRIBUTIONS}

KF and LR contributed to conception, design of the study, and wrote sections of the manuscript. KF collected, organized, and conducted the primary analysis of the data. All authors contributed to manuscript revision, read, and approved the submitted version.

\section{FUNDING}

This work was supported by The Australian Center for International Agricultural Research (ACIAR) under grant number SSS-2016-047.

\section{ACKNOWLEDGMENTS}

We would like to thank our co-researchers on this project, Tim Frewer, Connor Jolley, and Jason Alexandra, for their thoughtful contributions to discussions about gender in our project workshops.

Beling, A.E., Vanhulst, J., Demaria, F., Rabi, V., Carballo, A.E., and Pelenc, J. (2018). Discursive synergies for a 'great transformation' towards sustainability: pragmatic contributions to a necessary dialogue between human development, degrowth, and buen vivir. Ecol. Econ. 144, 304-313. doi: 10.1016/j.ecolecon.2017.08.025

Ben-Eli, M.U. (2018). Sustainability: definition and five core principles, a systems perspective. Sust. Sci. 13, 1337-1343. doi: 10.1007/s11625-018-0564-3

Benería, L., Berik, G., and Floro, M.S. (2016). Gender, Development and Globalisation: Economics as if All People Mattered. New York, NY: Routledge. doi: 10.4324/9780203107935

Benhabib, S. (1992). Situating the Self: Gender, Community and Postmodernism in Contemporary Ethics. Cambridge: Polity Press.

Berman, E.H. (1983). The Influence of the Carnegie, Ford, and Rockefeller Foundations on American Foreign Policy: The Ideology of Philanthropy. Albany, NY: State University of New York Press.

Beuchelt, T.D., and Badstue, L. (2013). Gender, nutrition- and climate-smart food production: opportunities and trade-offs. Food Security 5, 709-721. doi: 10.1007/s12571-013-0290-8

Bigler, C., Amacker, M., Ingabire, C., and Birachi, E. (2017). Rwanda's gendered agricultural transformation: a mixed-method study on the rural labour market, wage gap and care penalty. Women's Studies Int. Forum 64, 17-27. doi: 10.1016/j.wsif.2017.08.004

Boomgaard, P., and Hart, M.t. (eds.). (2011). “Introduction,” in Globalization, Environmental Change, and Social History. (Cambridge: Cambridge University Press), 1-26. doi: 10.1017/CBO9780511920677.001

Boserup, E., Tan, S.F., and Toulmin, C. (2013). Woman's Role in Economic Development. New York: Routledge. doi: 10.4324/9781315065892

Brandth, B. (1995). Rural masculinity in transition: gender images in tractor advertisements. J. Rural Stud. 11, 123-133. doi: 10.1016/0743-0167(95)00007-A

Calkin, S. (2015). Feminism, interrupted? Gender Dev. in the era of 'Smart Economics'. Progress Dev. Studies 15, 295-307. doi: 10.1177/1464993415592737

Carella, A., and Ackerly, B. (2017). Ignoring rights is wrong: repoliticizing gender equality and development with the rights-based approach. Int. Fem. J. Politics 19, 137-152. doi: 10.1080/14616742.2016.1 226640 
CEDAW (2016). General Recommendation No. 34 (2016) on the Rights of Rural Women. Geneva: Committee on the Elimination of Discrimination against Women, United Nations.

CGIAR (2018). GENNOVATE. Available online at: http://gender.cgiar.org/ themes/gennovate/ (accessed May 27, 2018).

Chant, S. (2008). The 'feminisation of poverty' and the 'feminisation' of antipoverty programmes: Room for revision? J. Dev. Studies 44, 165-197. doi: 10.1080/00220380701789810

Chant, S. (2012). The disappearing of "smart economics"? The World Dev. Report 2012 on gender equality: some concerns about the preparatory process and the prospects for paradigm change. Global Social Policy 12, 198-218. doi: $10.1177 / 1468018112443674$

Chant, S., and Gutmann, M.C. (2000). Mainstreaming Men Into Gender and Development: Debates, Reflections, and Experiences. Oxford: Oxfam. doi: 10.3362/9780855987916

Chant, S., and Gutmann, M.C. (2002). 'Men-streaming' gender? Questions for Gender Dev. policy in the twenty-first century. Progress Dev. Studies 2, 269-282. doi: 10.1191/1464993402ps041ra

Chant, S., and Sweetman, C. (2012). Fixing women or fixing the world? 'Smart economics', efficiency approaches, and gender equality in development. Gender Dev. 20, 517-529. doi: 10.1080/13552074.2012.731812

Charatsari, C., Istenič, M.C., and Lioutas, E.D. (2013). "I'd like to participate, but...": women farmers' scepticism towards agricultural extension/education programmes. Dev. Pract. 23, 511-525. doi: 10.1080/09614524.2013.790345

Charlesworth, H. (1995). "Human rights as men's rights," in Women's right-human rights: International feminist Perspectives, eds J. Peters \& A. Wolper. (New York, NY: Routledge), 103-113. doi: 10.4324/9781315656571-14

Cheshire, L., and Lawrence, G. (2005). Neoliberalism, Individualisation and Community: Regional Restructuring in Australia. Soc. Ident. 11, 435-445. doi: 10.1080/13504630500407869

Chua, P., Bhavnani, K.-K., and Foran, J. (2000). Women, culture, development: A new paradigm for development studies? Ethnic Racial Studies 23, 820-841. doi: 10.1080/01419870050110913

Colfer, C.J.P., Basnett, B.S., and Ihalainen, M. (2018). Making Sense of 'Intersectionality': A Manual for Lovers of People and Forests. Bogor Barat: CIFOR. doi: 10.17528/cifor/006793

Collins, A. (2018). Saying all the right things? Gendered discourse in climate-smart agriculture. J. Peasant Studies 45, 175-191. doi: 10.1080/03066150.2017.1377187

Collins, P.H., and Chepp, V. (2013). "Intersectionality," in The Oxford handbook of gender and politics, eds G. Waylen, K. Celis, J. Kantola \& L. Weldon. (Oxford: Oxford University Press), 57-87.

Cook, B., and Kothari, U. (2001). Participation: The New Tyranny? London: Zed Books.

Cornwall, A. (1997). Men, masculinity and 'gender in development'. Gender Dev. 5, 8-13. doi: 10.1080/741922358

Cornwall, A., and Rivas, A.-M. (2015). From 'gender equality and 'women's empowerment' to global justice: Reclaiming a transformative agenda for gender and development. Third World Q. 36, 396-415. doi: 10.1080/01436597.2015.1013341

Crenshaw, K. (1989). Demarginalizing the intersection of race and sex: a Black feminist critique of antidiscrimination doctrines, feminist theory and antiracist politics. Univ. Chicago Legal Forum 1, 139-167.

Davis, K. (2008). Intersectionality as buzzword: a sociology of science perspective on what makes a feminist theory successful. Femin. Theory 9, 67-85. doi: $10.1177 / 1464700108086364$

Deacon, D., Pickering, M., Golding, P., and Murdoch, G. (1999). Researching Communications: A Practical Guide to Methods in Media and Cultural Analysis. London: Arnold.

Devaux, A., Torero, M., Donovan, J., and Horton, D. (2018). Agricultural innovation and inclusive value-chain development: a review. J. Agribus. Dev. Emerg. Econ. 8, 99-123. doi: 10.1108/JADEE-06-2017-0065

Doss, C. (2018). Women and agricultural productivity: Reframing the Issues. Dev. Policy Rev. 36, 35-50. doi: 10.1111/dpr.12243

Ekbladh, D. (2011). The Great American mission: Modernization and the Construction of an American World Order. Princeton, NJ: Princeton University Press. doi: 10.1515/9781400833740
Elson, D. (2012). Review of World development report 2012: Gender equality and development. Global Soc. Policy 12, 178-183. doi: 10.1177/1468018112443673b

Ericksen, P.J. (2008). Conceptualizing food systems for global environmental change research. Global Environ. Change 18, 234-245. doi: 10.1016/j.gloenvcha.2007.09.002

Fairclough, N. (1995). Media Discourse. London: Edward Arnold.

FAO (2012). Voluntary Guidelines on the Responsible Governance of Tenure of Land, Fisheries and Forests in the Context of National Food Security. Rome: Food and Agriculture Organization of the United Nations.

FAO (2013). FAO Policy on Gender Equality: Attaining Food Security Goals in Agriculture and Rural Development. Rome: FAO.

FAO (2018). Scaling Up Agroecology Initiative: Transforming Food and Agricultural Systems in Support of the SDGs. A proposal prepared for the International Symposium on Agroecology. Rome: Food \& Agriculture Organisation.

Farnworth, C.R., Stirling, C.M., Chinyophiro, A., Namakhoma, A., and Morahan, R. (2018). Exploring the potential of household methodologies to strengthen gender equality and improve smallholder livelihoods: research in Malawi in maize-based systems. J. Arid Environ. 149, 53-61. doi: 10.1016/j.jaridenv.2017.10.009

Faxon, H.O. (2017). In the law \& on the land: finding the female farmer in Myanmar's National Land Use Policy. J. Peasant Studies 44, 1197-1214. doi: 10.1080/03066150.2017.1324424

Figueroa-Helland, L., Thomas, C., and Aguilera, A.P. (2018). Decolonizing food systems: food sovereignty, indigenous revitalization, and agroecology as counter-hegemonic movements. Perspect. Global Dev. Technol. 17, 173-201. doi: 10.1163/15691497-12341473

Francis, C., Lieblein, G., Gliessman, S., Breland, T.A., Creamer, N., Harwood, R., et al. (2003). Agroecology: the ecology of food systems. J. Sust. Agricult. 22, 99-118. doi: 10.1300/J064v22n03_10

Fraser, A.S. (1999). Becoming human: the origins and development of women's human rights. Hum. Rights Q. 21, 853-906. doi: 10.1353/hrq.1999. 0050

Gahman, L. (2015). Gun rites: hegemonic masculinity and neoliberal ideology in rural Kansas. Gender Place Cult. 22, 1203-1219. doi: 10.1080/0966369X.2014.970137

Gates, M.F. (2014). Putting women and girls at the center of development. Science 345, 1273-1275. doi: 10.1126/science. 1258882

Gómez, L.F., Ríos-Osorio, L.A., and Eschenhagen-Durán, M.L. (2016). Key concepts of agroecology science. a systematic review. Trop. Subtr. Agroecosy. 19, 109-117. Available online at: https://www.revista.ccba.uady.mx/ojs/index. php/TSA/article/view/2156

Guest, G., Bunce, A., and Johnson, L. (2006). How many interviews are enough? An experiment with data saturation and variability. Field Methods 18, 59-82. doi: $10.1177 / 1525822 X 05279903$

Healy, K. (2017). Fuck nuance. Sociol. Theory 35, 118-127. doi: $10.1177 / 0735275117709046$

Heggem, R. (2014). Exclusion and inclusion of women in Norwegian agriculture: Exploring different outcomes of the 'tractor gene'. J. Rural Stud. 34, 263-271. doi: 10.1016/j.jrurstud.2014.03.002

Hendrixson, A., Ojeda, D., Sasser, J.S., Nadimpally, S., Foley, E.E., and Bhatia, R. (2020). Confronting Populationism: Feminist Challenges to Population Control in an Era of Climate Change. Gender Place Culture 27, 307-315. doi: 10.1080/0966369X.2019.1639634

Holmelin, N.B. (2019). Competing gender norms and social practice in Himalayan farm management. World Dev. 122, 85-95. doi: 10.1016/j.worlddev.2019.05.018

Holt-Giménez, E., and Altieri, M.A. (2012). Agroecology, food sovereignty, and the new green revolution. Agroecol. Sust. Food Syst. 37, 90-102. doi: 10.1080/10440046.2012.716388

Hovorka, A.J. (2006). The No. 1 Ladies' Poultry Farm: A feminist political ecology of urban agriculture in Botswana. Gender Place Cult. 13, 207-225. doi: 10.1080/09663690600700956

IAASTD (2009). Agriculture at a Crossroads. Washington, DC: International Assessment of Agricultural Knowledge, Science and Technology for Development.

Jaquette, J.S. (2017). Women/gender and development: the growing gap between theory and practice. Studies Comp. Int. Dev. 52, 242-260. doi: 10.1007/s12116-017-9248-8 
Jerneck, A. (2018). Taking gender seriously in climate change adaptation and sustainability science research: views from feminist debates and sub-Saharan small-scale agriculture. Sust. Sci. 13, 403-416. doi: 10.1007/s11625-017-0464-y

Kabeer, N. (1994). Reversed Realities: Gender Hierarchies in Development Thought. London: Verso.

Kangmennaang, J., Kerr, R.B., Lupafya, E., Dakishoni, L., Katunda, M., and Luginaah, I. (2017). Impact of a participatory agroecological development project on household wealth and food security in Malawi. Food Secur. 9, 561-576. doi: 10.1007/s12571-017-0669-z

Kantola, J., and Lombardo, E. (2017). Feminist political analysis: exploring strengths, hegemonies and limitations. Fem. Theory 18, 323-341. doi: $10.1177 / 1464700117721882$

Kantor, P., Morgan, M., and Choudhury, A. (2015). Amplifying outcomes by addressing inequality: the role of gender-transformative approaches in agricultural research for development. Gender Technol. Dev. 19, 292-319. doi: $10.1177 / 0971852415596863$

Katherine, J. (2018). Get your farm in the fight: farm masculinity in world War II. Agricult. Hist. 92, 5-20. doi: 10.3098/ah.2018.092.1.005

Kawarazuka, N., Locke, C., McDougall, C., Kantor, P., and Morgan, M. (2017). Bringing analysis of gender and social-ecological resilience together in smallscale fisheries research: challenges and opportunities. Ambio 46, 201-213. doi: 10.1007/s13280-016-0814-5

Kiptot, E., and Franzel, S. (2012). Gender and agroforestry in Africa: a review of women's participation. Agrofor. Syst. 84, 35-58. doi: 10.1007/s10457-011-9419-y

Klugman, J., Hanmer, L., Twigg, S., Hasan, T., McCleary-Sills, J., and Santamaria, J. (2014). Voice and Agency: Empowering Women and Girls for Shared Prosperity. Washington, DC: The World Bank. doi: 10.1596/978-1-4648-0359-8

Koczberski, G. (1996). From Mexico to Beijing: 'Women in development' twenty five years on. Austr. Geograph. Studies 34, 138-148. doi: 10.1111/j.1467-8470.1996.tb00111.x

Koczberski, G. (1998). Women in development: A critical analysis. Third World Quarterly 19, 395-409. doi: 10.1080/01436599814316

Koczberski, G., and Curry, G.N. (2016). Changing generational values and new masculinities amongst smallholder export cash crop producers in Papua New Guinea. Asia Pacific J. Anthropol. 17, 268-286. doi: $10.1080 / 14442213.2016 .1178323$

Korieh, C.J. (2001). The invisible farmer? Women, gender, and colonial agricultural policy in the Igbo region of Nigeria, c. 1913-1954. Afric. Econ. Hist. 29, 117-162. doi: 10.2307/3601709

Kristjanson, P., Bryan, E., Bernier, Q., Twyman, J., Meinzen-Dick, R., Kieran, C., et al. (2017). Addressing gender in agricultural research for development in the face of a changing climate: Where are we and where should we be going? Int. J. Agricult. Sustainab. 15, 482-500. doi: 10.1080/14735903.2017.1336411

Lado, C. (1992). Female labour participation in agricultural production and the implications for nutrition and health in rural Africa. Soc. Sci. Med. 34, 789-807. doi: 10.1016/0277-9536(92)90366-X

Lazar, M. M. (ed.). (2005). Feminist Critical Discourse Analysis: Gender, Power and Ideology in Discourse. Houndmills: Palgrave Macmillan. doi: $10.1057 / 9780230599901$

Leahy, T., and Brown, D.J. (2016). "People are Trying to be Modern": Food Insecurity and the Strategies of the Poor. Forum Dev. Studies 43, 489-510. doi: $10.1080 / 08039410.2016 .1233136$

Leap, B. (2017). Survival narratives: Constructing an intersectional masculinity through stories of the rural/urban divide. J. Rural Stud. 55, 12-21. doi: 10.1016/j.jrurstud.2017.07.010

Leslie, I.S. (2017). Queer farmers: sexuality and the transition to sustainable agriculture. Rural Sociol. 82, 747-771. doi: 10.1111/ruso.12153

Leslie, I.S., Wypler, J., and Bell, M.M. (2019). Relational agriculture: gender, sexuality, and sustainability in U.S. Farm. Soc. Natu. Resourc. 32, 853-874. doi: $10.1080 / 08941920.2019 .1610626$

Levien, M. (2017). Gender and land dispossession: a comparative analysis. J. Peasant Studies 44, 1111-1134. doi: 10.1080/03066150.2017.1367291

Little, J. (1997). Constructions of rural women's voluntary work. GenderPlace Cult. 4, 197-210. doi: 10.1080/09663699725431

Lockie, S. (2000). "Rural gender relations and landcare," in Critical Landcare, eds S. Lockie \& F. Vanclay. (Wagga Wagga, NSW: Centre for Rural Social Research, Charles Sturt University).
Mama, A. (2007). "Critical connections: Feminist studies in African contexts," in Feminisms in Development: Contradictions, Contestations and Challenges, eds A. Cornwall, E. Harrison \& A. Whitehead. (London: Zed Books), 150-160.

Masika, R., and Bailur, S. (2015). Negotiating women's agency through ICTs: A comparative study of Uganda and India. Gend. Technol. Dev. 19, 43-69. doi: $10.1177 / 0971852414561615$

McCall, L. (2014). The complexity of intersectionality. Signs 40, 1771-1800. doi: $10.1086 / 426800$

McDougall, C., Leeuwis, C., Bhattarai, T., Maharjan, M.R., and Jiggins, J. (2013). Engaging women and the poor: Adaptive collaborative governance of community forests in Nepal. Agricult. Hum. Values 30, 569-585. doi: 10.1007/s10460-013-9434-x

Menon, N., and Rodgers, Y. (2009). International trade and the gender wage gap: New evidence from india's manufacturing sector. World Dev. 37, 965-981. doi: 10.1016/j.worlddev.2008.09.009

Midgley, J. (2006). Gendered economies: Transferring private gender roles into the public realm through rural community development. J. Rural Stud. 22, 217-231. doi: 10.1016/j.jrurstud.2005.08.014

Mies, M., and Shiva, V. (1993). Ecofeminism. New York, NY: Zed Books.

Moser, C.O.N. (1989). Gender planning in the third world: Meeting practical and strategic gender needs. World Dev. 17, 1799-1825. doi: 10.1016/0305-750X(89)90201-5

Mudege, N.N., Chevo, T., Nyekanyeka, T., Kapalasa, E., and Demo, P. (2016). Gender norms and access to extension services and training among potato farmers in dedza and ntcheu in Malawi. J. Agricult. Educ. Exten. 22, 291-305. doi: 10.1080/1389224X.2015.1038282

Mudege, N.N., Mdege, N., Abidin, P.E., and Bhatasara, S. (2017). The role of gender norms in access to agricultural training in Chikwawa and Phalombe, Malawi. Gender Place Cult. 24, 1689-1710. doi: 10.1080/0966369X.2017.1383363

Naranjo, S. (2011). Enabling food sovereignty and a prosperous future for peasants by understanding the factors that marginalise peasants and lead to poverty and hunger. Agricult. Hum. Values29, 231-246. doi: 10.1007/s10460-011-9345-7

Nightingale, A.J. (2011). Bounding difference: Intersectionality and the material production of gender, caste, class and environment in Nepal. Geoforum 42, 153-162. doi: 10.1016/j.geoforum.2010.03.004

Norton, B. (2005). Sustainability: A Philosophy of Adaptive Ecosystem Management. Chicago: University of Chicago Press. doi: 10.7208/chicago/9780226595221.001.0001

Ola-David, O., and Oyelaran-Oyeyinka, O. (2014). Smart economics: inclusive growth, poverty alleviation and decent employment in Nigeria. Available online at: https://dx.doi.org/10.2139/ssrn.2505264 (accessed June 13, 2014). doi: 10.2139/ssrn.2505264

Otieno, P.E., Farnworth, C.R., and Banda, N. (2016). NOTE 26: Involving Men in Nutrition. Lausanne: GFRAS.

Pahl-Wostl, C. (2019). Governance of the Water-Energy-Food Security Nexus: A Multi-Level Coordination Challenge. Environ. Sci. Policy. 92, 356-367. doi: 10.1016/j.envsci.2017.07.017

Parpart, J. L., Rai, S. M., and Staudt, K. (eds.). (2002). Rethinking Empowerment: Gender Development in a Globa/Local World. London: Routledge. doi: $10.4324 / 9780203220078$

Peter, G., Bell, M.M., Jarnagin, S., and Bauer, D. (2000). Coming back across the fence: Masculinity and the transition to sustainable agriculture. Rural Sociol. 65, 215-233. doi: 10.1111/j.1549-0831.2000.tb0 0026.x

Pini, B. (2005). The third sex: women leaders in australian agriculture. Gend. Work Organiz. 12, 73-88. doi: 10.1111/j.1468-0432.2005.00263.x

Portman, A. (2018). Food sovereignty and gender justice. J. Agricult. Environ. Ethics 31, 455-466. doi: 10.1007/s10806-018-9739-2

Poulsen, E. (2016). Gender Mainstreaming in Agricultural Value Chains: Promising Experiences and the Role of Rural Advisory Services. Lausanne: GFRAS.

Pretty, J. (2008). Agricultural sustainability: concepts, principles and evidence. Philosoph. Trans. R. Soc. B Biol. Sci. 363, 447-465. doi: 10.1098/rstb.2007.2163

Punch, K.F. (1998). Introduction to Social Research: Quantitative and Qualitative Approaches. London: Sage.

Quaye, W., Fuseini, M., Boadu, P., and Asafu-Adjaye, N.Y. (2019). Bridging the gender gap in agricultural development through gender responsive extension and rural advisory services delivery in Ghana. J. Gender Stud. 28, 185-203. doi: $10.1080 / 09589236.2017 .1419941$ 
Ragasa, C. (2014). "Improving gender responsiveness of agricultural extension," in Gender in Agriculture, eds. A.R. Quisumbing, R. Meinzen-Dick, T.L. Raney, A. Croppenstedt, J.A. Behrman \& A. Peterman. (Dordrecht: Springer), 411-430.

Ragsdale, K., Read-Wahidi, M.R., Wei, T., Martey, E., and Goldsmith, P. (2018). Using the WEAI+ to explore gender equity and agricultural empowerment: baseline evidence among men and women smallholder farmers in Ghana's Northern Region. J. Rural Stud. 64, 123-134. doi: 10.1016/j.jrurstud.2018.09.013

Rai, S.M., Hoskyns, C., and Thomas, D. (2014). Depletion: The cost of social reproduction. Int. Femi. J. Politics 16, 86-105. doi: 10.1080/14616742.2013.789641

Ramazanoglu, C., and Holland, J. (2002). Feminist Methodology: Challenges and Choices. London: Sage. doi: 10.4135/9781849209144

Ransom, E., and Bain, C. (2011). Gendering agricultural aid: an analysis of whether international development assistance targets women and gender. Gender Soc. 25, 48-74. doi: 10.1177/0891243210392571

Sachs, C., and Alston, M. (2010). Global shifts, sedimentations, and imaginaries: an introduction to the special issue on women and agriculture. Signs 35, 277-287. doi: $10.1086 / 605618$

Scheer, V.L., Stevens, P.E., and Mkandawire-Valhmu, L. (2016). Raising questions about capitalist globalization and universalizing views on women. A transnational feminist critique of the World Dev. Report: Gender equality and development. Adv. Nurs. Sci. 39, 65-107. doi: 10.1097/ANS.0000000000000120

Scoones, I., and Thompson, J. (1994). Beyond Farmer First: Rural People's Knowledge, Agricultural Research and Extension Practice. London: Intermediate Technology Publications. doi: 10.3362/9781780442372

Shaw, A., and Wilson, K. (2020). The Bill and Melinda Gates Foundation and the necro-populationism of 'climate-smart' agriculture. Gender Place Culture. 27, 370-393. doi: 10.1080/0966369X.2019.1609426

Shortall, S. (2015). Gender mainstreaming and the common agricultural policy. Gender Place Cult. 22, 717-730. doi: 10.1080/0966369X.2014.939147

Silverman, D. (2001). Interpreting Qualitative Data: Methods for Analysing Text, Talk, and Interaction. London: Sage.

Slätmo, E., Fischer, K., and Röös, E. (2017). The framing of sustainability in sustainability assessment frameworks for agriculture. Sociol. Rural. 57, 378-395. doi: $10.1111 /$ soru. 12156

Smith, A. (2005). Conquest: Sexual Violence and American Indian Genocide. New York, NY: South End Press. doi: 10.1515/9780822374817

Squier, S. (2010). Liminal livestock. Signs 35, 477-502. doi: 10.1086/605511

Sumberg, J., Thompson, J., and Woodhouse, P. (2013). Why agronomy in the developing world has become contentious. Agricult. Hum. Values 30, 71-83. doi: 10.1007/s10460-012-9376-8

Tavenner, K., and Crane, T.A. (2018). Gender power in Kenyan dairy: cows, commodities, and commercialization. Agricult. Hum. Values 35, 701-715. doi: 10.1007/s10460-018-9867-3

The Bill and Melinda Gates Foundation (2012). Creating Gender-Responsive Agricultural Development Programs. Seattle, WA: The Bill and Melinda Gates Foundation.

Tinker, I. (1976). "The adverse impact of development on women," in Women and world development, eds I. Tinker \& M.B. Bramsen. (Washington, DC: Overseas Development Council), 22-34.
Tinker, I. (1990). "A context for the field and the book," in Persistent inequalities: Women and world development, ed I. Tinker. (Oxford: Oxford University Press), 3-13.

Tong, R., and Botts Fernandes, T. (2018). Feminist Thought: A More Comprehensive Introduction. New York London: Routledge, Taylor and Francis Group. doi: $10.4324 / 9780429493836$

UN Women (2015). The Cost of the Gender Gap in Agricultural Agricultural Productivity in Malawi, Tanzania, and Uganda. New York, NY: UN Women.

Van den Broeck, G., and Kilic, T. (2019). Dynamics of off-farm employment in Sub-Saharan Africa: a gender perspective. World Dev. 119, 81-99. doi: 10.1016/j.worlddev.2019.03.008

van Dijk, T.A. (1991). Racism and the Press. London: Routledge.

Waltz, A. (2016). The women who feed us: Gender empowerment (or lack thereof) in rural Southern Brazil. J. Rural Stud. 47, 31-40. doi: 10.1016/j.jrurstud.2016.07.009

Wanner, T., and Wadham, B. (2015). Men and masculinities in international development: 'Men-streaming' gender and development? Dev. Policy Rev. 33, 15-32. doi: 10.1111/dpr.12090

Wilson, K. (2015). Towards a radical re-appropriation: Gender, development and neoliberal feminism. Dev. Change 46, 803-832. doi: 10.1111/dech.12176

Winter, E., Marton, S.M., Baumgart, L., Curran, M., Stolze, M., and Schader, C. (2020). Comparing the sustainability performance of typical conventional and certified coffee production systems in Brazil and Ethiopia using the FAO SAFA Guidelines. Front. Sust. Food Syst. 4. doi: 10.3389/fsufs.2020. 00049

World Bank (2007). World Development Report: Agriculture for Development. Washington, DC: The World Bank).

World Bank (2009). The Gender in Agriculture Sourcebook. Washington, DC: The World Bank.

World Bank (2011). World Deelopment Report 2012: Gender Equality and Development. Washington, DC: World Bank Publications.

Zossou, E., Arouna, A., Diagne, A., and Agboh-Noameshie, R.A. (2017). Gender gap in acquisition and practice of agricultural knowledge: Case study of rice farming in west africa. Exp. Agricul. 53, 566-577. doi: $10.1017 /$ S0014479716000582

Zuckerman, E. (2007). Critique: Gender Equality as Smart Economics: World Bank Group Gender Action Plan (GAP) (Fiscal Years 200710) [Online]. Gender Action. Available online at: http://www. genderaction.org/images/04.22.08_EZ-GAPlanCritique.pdf (accessed May $28,2018)$.

Conflict of Interest: The authors declare that the research was conducted in the absence of any commercial or financial relationships that could be construed as a potential conflict of interest.

Copyright $\odot 2021$ Farhall and Rickards. This is an open-access article distributed under the terms of the Creative Commons Attribution License (CC BY). The use, distribution or reproduction in other forums is permitted, provided the original author(s) and the copyright owner(s) are credited and that the original publication in this journal is cited, in accordance with accepted academic practice. No use, distribution or reproduction is permitted which does not comply with these terms. 